\title{
Effect of bergenin on the kidney of C57BL/6J mice with high fat-diet induced oxidative stress
}

\author{
Sagadevan Ambika and Ramalingam Saravanan* \\ Department of Biochemistry and Biotechnology, Annamalai University, \\ Annamalai Nagar- 608 002, Tamil Nadu, India \\ *Assistant professor: Email : jayamsaranbio@gmail.com
}

Keywords: high fat diet; bergenin; nephritic markers; lipid peroxidation; antioxidant

\begin{abstract}
The present study evaluated the protective effect of bergenin on high fat diet (HFD) induced diabetic mice. C57BL/6J mice were segregated in two groups, one fed standard diet (NC) and the other fed HFD for 16 weeks. Mice were fed continuously with high fat diet for 16 weeks and subjected to intragastric administration of bergenin $(10,20$ and $40 \mathrm{mg} / \mathrm{kg}$ body weight (BW)), metformin $(25 \mathrm{mg} / \mathrm{kg} \mathrm{BW}) 9$ to 16 weeks. At the end of the treatment nephritic markers, lipid peroxidation product, antioxidant and histopathological examination were carried out to assess the efficacy of the treatment. HFD fed mice showed increased plasma glucose, insulin, altered nephritic markers, antioxidant and histopathological abnormalities. Oral Treatment with bergenin $(40 \mathrm{mg} / \mathrm{kg}$ BW) showed near normalized levels of plasma glucose, lipid peroxidation product, antioxidants, improved insulin and reduced kidney damage. The effects of bergenin were comparable with standard drug, metformin. These data suggest that bergenin protect kidney from deleterious effect of glucose.
\end{abstract}

\section{INTRODUCTION}

Diabetes mellitus (DM) is a complex metabolic disease characterized by high blood glucose levels and a disorder of carbohydrate, fat and protein metabolism. The abnormal increase of blood glucose in diabetes will result in long-term damage and dysfunction of various organs including the eyes, kidneys, nerves and blood vessels [1]. Diabetic nephropathy (DN) is one of the most devastating diabetes complications and the leading cause of end stage renal disease [2]. DN is caused by both metabolic alterations (hyperglycaemia and possibly hyperlipidaemia) and haemodynamic alterations (systemic and glomerular hypertension). Oxidative stress consumes nitric oxide, which prevents flow-mediated dilation (FMD) of blood vessels (endothelial dysfunction), subjecting the endothelium to injury. This leads to production of cytokines, acceleration of inflammation, worsening of blood vessel rigidity due to atherosclerosis, further impairment of FMD and susceptibility to oxidative stress. Inflammation, endothelial dysfunction and oxidative stress can be thought of as a "vicious cycle" that leads to significant kidney damage and cardiovascular events. The injurious effects of hyperglycemia induce vascular damage through complex overlapping pathways; formation of advanced glycation end products (AGE), activation of protein kinase $\mathrm{C}$ and generation of reactive oxygen species (ROS) [3]. Growing evidence suggests that ROS may play important role in the initiation and progression of DN. The effect of antioxidant therapy is well-documented in cell and animal studies [4]. Among the various therapeutic strategies, combination of antihyperglycemic, antihyperlipidemic, antihypertensive, and antioxidants may be beneficial for the prevention of diabetes complication.

Growing prevalence in unfastened-radical biology and lack of effective therapies for maximum chronic diseases, the usefulness of the nutritional inclusion of herbal antioxidants found in plant foods is a crucial fitness-defensive and sickness-preventing component in people. Plants are rich source of bioactive components; the most important of these are polyphenols and flavonoids compounds. They show off high antioxidant homes that terminate free-radical mediated reactions with the aid of donating hydrogen atom or an electron to the radicals $[5,6]$. Bergenin is $(\mathrm{C}$-glucoside of 4-O-methylgallic acid) polyphenol compound. It is dihydroisocoumarin derivative isolated from 
several medicinal plants such as Ficuus racemosa [7], Mallotus japonicas[8], Bergenia crassifolia, Caesalpinia digyna, Astibe thunbergii, Ardisia japonica plant and also other genera [9]. Bergenin contains five hydroxyl groups which are consider to be potentially active and it exhibit various biological activities such as antioxidant [10], hepatoprotective [11], antiarrhythmic [12], antimicrobial, antiviral and antiulcerogenic activities [13], anti-inflammatory [14]. Bergenin is reported as insulin sensitisers [7] and has potential antidiabetic effect [15]. Hence, the present study was designed to evaluate the protective effect of bergenin in early DN in HFD induced diabetic mice.

\section{MATERIALS AND METHODS}

\subsection{Chemicals}

Bergenin was purchased from Carbo synth (Compton, Berkshire, UK). All other chemicals used in this study were of analytical grade obtained from HIMEDIA and S.D. Fine chemicals Research laboratories Pvt. Ltd (Mumbai, Maharashtra, India).

\subsection{Experimental animals}

Male C57BL/6J mice 3 weeks of age were obtained from NIN Hyderabad and housed in polypropylene cages. Animals were maintained under standard conditions with a $12 \mathrm{~h}$ light/dark cycle. The animals received a standard pellet diet (Karnataka State Agro Corporation Ltd., Agro feeds division, Bangalore, India) and water ad libitum. After acclimatization for period of 1 week, mice were randomly divided into six groups. The animals used in the present study were cared and maintained as per the principles and guidelines of the Institutional Animal Ethical Committee (IAEC), Annamalai Nagar, in accordance with the Indian National law on animal care and use. The study protocols were approved by the Institutional Animal Ethics Committee of Rajah Muthiah Medical College and Hospital, Annamalainagar (Reg No. 160/1999/CPCSEA, Proposal number: 913).

\subsection{Experimental induction of diabetes}

The type 2 diabetes was induced through HFD. The standard diet which is commercially obtained from Sai Enterprises, Chennai, had a fat composition of $4.2 \%$. The beef tallow based high fat diet was composed of protein $-17.7 \mathrm{~g}$, fat-35.2 g, carbohydrate- $34.5 \mathrm{~g}$, fibre- $3.4 \mathrm{~g}$, minerals - 6.8 $\mathrm{g}$ and vitamins- $1.8 \mathrm{~g}$. Mice (6 nos.) from normal control group (group I) were fed standard diet for a period of 16 weeks. Mice from rest of the groups (group II-VI) were fed high fat diet for a period of 16 weeks. At the end of $8^{\text {th }}$ week, the mice from all the groups were tested for blood glucose levels. Mice with blood glucose level of $220 \mathrm{mg} / \mathrm{dL}$ and above were considered to have developed insulin resistance and were subjected to intragastric administration of various doses of bergenin and metformin (as mentioned in the experimental design) during 8 to 16 weeks.

\subsection{Diet and experimental design}

The experimental design consisted of six groups of mice. Group I: Normal control (NC) mice fed with a standard diet for 16 weeks. Group II: HFD diabetic mice fed with high fat diet for a period of 16 weeks. Group III: NC mice fed with standard diet for 16weeks and administered with bergenin $(10 \mathrm{mg} / \mathrm{kg} \mathrm{BW})$ by gavage for the last 8 weeks. Group IV: HFD diabetic mice administered with bergenin $(20 \mathrm{mg} / \mathrm{kg} \mathrm{BW})$ by gavage for the last 8 weeks. Group V: HFD diabetic mice administered with bergenin $(40 \mathrm{mg} / \mathrm{kg} \mathrm{BW})$ by gavage for the last 8 weeks. Group VI: HFD diabetic mice administered with metfomin $(25 \mathrm{mg} / \mathrm{kg} \mathrm{BW})$ by gavage for the last 8 weeks. At the end of experimental period mice were fasted overnight. The mice were sacrificed by cervical dislocation. Blood was collected by cutting the jugular vein into heparinized glass tubes. Plasma was obtained from blood samples after centrifugation $(1500 \mathrm{~g}$ for $10 \mathrm{~min})$ and stored at $4{ }^{\circ} \mathrm{C}$. Kidney tissue was excised immediately from the mice and washed in ice-cold isotonic saline and blotted with a filter paper. The dosage of bergenin was selected from the dose-fixation study using three different doses (10 mg, $20 \mathrm{mg}$ and $40 \mathrm{mg} / \mathrm{kg} \mathrm{BW}$ ). From the results of the study (Table 1), we 
found that $40 \mathrm{mg} / \mathrm{kg} \mathrm{BW}$ to be effective in lowering glucose and insulin levels when compared to $10 \mathrm{mg}$ and $20 \mathrm{mg} / \mathrm{kg} \mathrm{BW}$. Thus, the $40 \mathrm{mg} / \mathrm{kg} \mathrm{BW}$ was taken as the optimum dose for treatment.

\subsection{Biochemical analysis}

Plasma glucose was estimated by the method of Trinder (1969) [16]. Plasma insulin was measured by the method of Burgi et al. (1988) [17]. Serum urea was estimated by the method of Fawcett and Scott (1960) [18], uric acid by the enzymatic method described by Caraway (1955) [19] and creatinine was estimated using the method of Tietz, 1987. Superoxide dismutase (SOD) in the kidney tissues was assayed by the method of Kakkar et al. (1984) [20]. The activity of catalase (CAT) in the kidney tissues was determined by the method of Sinha (1972) [21]. The activity of glutathione peroxidase (GPx) in the kidney tissues was measured by the method of Rotruck et al., (1973) [22]. Reduced glutathione (GSH) in the kidney tissues was estimated by the method of Ellman (1959) [23]. Vitamin C in the kidney tissues was estimated by the method of Roe and Kuether (1943) [24]. Vitamin E in the kidney tissues was estimated by the method of Baker et al., (1980) [25]. TBARS and LHP (Lipid hydroperoxide) in kidney tissues were estimated by the methods of Niehaus and Samuelsson (1968) [26] and Jiang et al., (1992) [27], respectively.

\subsection{Histological examination}

For histological analysis, sections from the kidney of mice from NC, HFD, HFD + bergenin and HFD + metformin were fixed in $10 \%$ buffered formalin for $24 \mathrm{~h}$ and embedded in paraffin. Tissue sections were deparaffinized, stained with haematoxylin-eosin (H\&E) and examined under microscope at 400x magnification.

\subsection{Statistical analysis}

The results were expressed as mean \pm standard deviation (SD) for 6 mice in each group. Data were analysed by one- way analysis of variance followed by Duncan's multiple range test (DMRT) using SPSS version 16 (SPSS, Chicago,IL). Post hoc testing was performed for intergroup comparisons using the least significance difference (LSD) test; $p$ values $\backslash 0.05$ were considered as significant.

\section{RESULTS}

Figure 1 delineate significant increase in plasma glucose and insulin levels were noted in HFD induced diabetic mice group than in the control group. Bergenin treatment to HFD mice reduced glucose and insulin level to near normal. These values were compared with metformin activity.

Table 1 shows increased serum activities of urea, uric acid and creatinine were found in HFD induced diabetic mice, indicating damage to kidney cells. Treatment of HFD induced diabetic mice with bergenin resulted in significantly lower urea, uric acid and creatinine activity. These values were compared with metformin activity. Table 2 lists TBARS and LHP levels in the different groups. Significantly higher TBARS and LHP levels were found in HFD induced diabetic mice compared with control mice. In bergenin treated HFD induced diabetic mice, TBARS and LHP levels were significantly lower compared with metformin.

Table 3 lists the activities of enzymatic and non-enzymatic antioxidants in the kidney of the different groups. The activities of enzymatic antioxidants SOD, CAT, GPx were significantly lowered in HFD induced diabetic mice. The GSH, as well as vitamin $\mathrm{C}$ and $\mathrm{E}$ levels, were significantly decreased in HFD-induced diabetic mice compared with controls. In bergenin treated HFD-induced diabetic mice, these parameters returned to normal levels.

Histopathology sections of kidney tissues were given in figure 2 HFD fed mice showed focal proliferative glomerulo nephritis with mild increase in cellularity in cortex and closely packed tubules with normal medulla in diabetic mice. Treatment with bergenin and metformin groups showed normal glomeruli and medulla histology comparable with untreated control mice. 


\section{DISCUSSION}

Immoderate power consumption from HFD results in a boom in energy as fats, accompanied through an elevation in mitochondrial macronutrient oxidation, favoring an excessive production of ROS generation, thereby mounted oxidative stress [28]. HFD feeding has been documented to result in dyslipidemia, hyperglycemia and hyperinsuliunemia in mice [29]. Our results are consistent with previous studies which found that consumption of HFD markedly induces an increase in glucose and insulin. In the present study bergenin treatment significantly reduced the glucose and insulin level. Kumar et al (2012) also reported that bergenin has antidiabetic activity in streptozotocin nicotinamide induced diabetic rats [15].

Oxidative stress plays an important role within the pathogenesis and progression of renal sickness [30]. HFD induces alteration of renal lipid metabolism via an imbalance between lipogenesis and lipolysis within the kidney, as well as systemic metabolic abnormalities and next renal lipid accumulation and lipid peroxidation leading to renal harm [31]. The accumulated adipose tissue around the kidneys penetrates into the medullary sinuses, increases intrarenal pressures causing damage to the renal tissue. Damaged renal tissue acts as a source of ROS generation and develops lipid peroxidation. An accelerated lipid peroxidation within the kidney tissue is probably concerned in the onset of kidney lesions within the rodent models of obesity [32]. Elevated ranges of TBARS and LHP inside the kidney of HFD precipitated diabetic mice is regular with a preceding record that HFD induces oxidative damage [33]. The antioxidant enzymes along with SOD, CAT and GPX are themselves liable to reactive oxygen species (ROS) assault [34]. The decreased SOD activity in HFD induced diabetic mice can be attributed to inactivation of the enzyme because of glycation of Lys122 and Lys128 residues [35]. Reduced GSH, vitamins E and C may be because of elevated utilization to fight free radicals and/or decreased regeneration from their oxidized forms. The biochemical evaluation exhibited significant lower in enzymatic and nonenzymatic antioxidants with great increase in lipid peroxidation markers in HFD caused diabetic mice. In our examine, intragastric administration of bergenin to HFD mice confirmed recovery of the degrees of enzymatic and nonenzymatic antioxidants with reduced lipid peroxidation byproducts. Accordingly, our look at suggests that bergenin ought to definitely impair the generation of oxidative stress thereby lowering the risk of HFD-precipitated kidney injury. Nazir et al., reported that bergenin has strong antioxidant properties by scavenging the free radicals [36].

In general, creatinine level is considered to assess kidney function [37]. Elevated levels of serum creatinine, urea and uric acid were observed in diabetic kidney. Blood urea is produced as a result of protein breakdown and formed in the liver which carried via the bloodstream to the kidneys to be eliminated. Urea is hydrolysed in the presence of water and urease to produce ammonia and carbon dioxide. Uric acid inside the sample is oxidized by using uricase to allantoin. The assay of creatinine turned into based totally on the response of creatinine with alkaline picrate. Creatinine is a breakdown product formed in certain muscular tissues and carried thru the bloodstream and eliminated by way of the kidneys. If the kidneys dysfunction, they are unable to dispose of the usual amount of these materials and as an end result, the blood urea and creatinine stages will enhance [38]. Moreover, these elevations were found to be associated with interstitial atrophy, epithelial necrosis as well as atrophic changes in glomeruli, and thus DN [39]. Diabetic mice showed significant increase in serum creatinine, urea and uric acid levels which were significantly reduced after treatment with bergenin indicating recovery toward normal level. Histopathological observations in the kidney sections showed focal proliferative glomerulonephritis with mild increase in cellularity and closely packed tubules with normal medulla of HFD induced diabetic mice. Kidney sections from HFD + bergenin and HFD + Metformin groups showed normal glomeruli with closely packed tubules comparable with untreated control mice 


\section{CONCLUSION}

According to the studies on HFD induced diabetic mice administration of bergenin reduced the hyperglycemia, hyperinsulinemia, oxidative stress, improved antioxidant status and slowing the progession of early DN. Our histological studies reveal the protective effect of bergenin against kidney damage. Our study suggests that bergenin can serve as a beneficial compound in management of type 2 diabetes. Further studies will be in progess to elicit the exact mechanism of bergenin for its antidiabetogenic effect.

\section{Acknowledgements}

The authors thoughtfully wish to place on record with gratitude to university grant commission (UGC), New Delhi, which rendered financial support by granting SRF to the scholar Ambika. S.

Table 1. Effect of Bergenin on urea, uric acid, creatinine of serum in experimental mice

\begin{tabular}{|c|c|c|c|}
\hline Group & Urea (mg/dL) & Uric acid (mg/dL) & Creatinine (mg/dL) \\
\hline Normal control & $23.19 \pm 1.32^{\mathrm{a}}$ & $1.44 \pm 0.08^{\mathrm{a}}$ & $0.96 \pm 0.05^{\mathrm{a}}$ \\
\hline HFD & $49.42 \pm 2.87^{\mathrm{b}}$ & $3.90 \pm 0.19^{b}$ & $3.09 \pm 0.22^{\mathrm{b}}$ \\
\hline HFD + BGN(10 mg/kg BW) & $40.18 \pm 2.65^{\mathrm{c}}$ & $3.20 \pm 0.17^{\mathrm{c}}$ & $2.11 \pm 0.19^{c}$ \\
\hline HFD + BGN(20 mg/kg BW $)$ & $35.33 \pm 2.43^{\mathrm{d}}$ & $2.99 \pm 0.16^{\mathrm{d}}$ & $1.87 \pm 0.14^{\mathrm{d}}$ \\
\hline HFD + BGN(40 mg/kg BW) & $27.25 \pm 2.21^{\mathrm{e}}$ & $2.85 \pm 0.16^{\mathrm{e}}$ & $1.20 \pm 0.07^{\mathrm{e}}$ \\
\hline HFD + metformin $(25 \mathrm{mg} / \mathrm{kg} \mathrm{BW})$ & $25.28 \pm 1.56^{\mathrm{a}}$ & $1.98 \pm 0.10^{\mathrm{f}}$ & $0.99 \pm 0.06^{\mathrm{a}}$ \\
\hline
\end{tabular}

Values that have a different superscript letter $(\mathrm{a}, \mathrm{b}, \mathrm{c}, \mathrm{d}, \mathrm{e}, \mathrm{f})$ differ significantly with each other $(\mathrm{p}<0.05$,DMRT). BGN-bergenin, MET-metformin

Table 2. Effect of Bergenin on TBARS and LOOH in the kidney of HFD-fed C57BL/6J mice

\begin{tabular}{lcc}
\hline \multicolumn{1}{c}{ Group } & TBARS & LOOH \\
\hline Normal control & $1.43 \pm 0.07^{\mathrm{a}}$ & $69.72 \pm 3.89^{\mathrm{a}}$ \\
HFD & $3.85 \pm 0.18^{\mathrm{b}}$ & $153.31 \pm 9.32^{\mathrm{b}}$ \\
HFD + BGN (40 $\mathbf{~ m g / k g ~ B W ) ~}$ & $1.60 \pm 0.08^{\mathrm{cd}}$ & $85.54 \pm 5.67^{\mathrm{c}}$ \\
HFD + MET (25 $\mathbf{~ g g / k g ~ B W ) ~}$ & $1.51 \pm 0.07^{\mathrm{da}}$ & $74.09 \pm 4.60^{\mathrm{a}}$ \\
\hline
\end{tabular}

Values that have a different superscript letter (a, b, c,d) differ significantly with each other $(\mathrm{p}<0.05$,DMRT).

Table 3. Effect of Bergenin on the activities of enzymatic and non enzymatic antioxidant in the kindey of diabetic and normal mice

\begin{tabular}{|c|c|c|c|c|}
\hline Group & Normal control & HFD & $\begin{array}{l}\text { HFD+BGN } \\
(40 \mathrm{mg} / \mathrm{kg} \mathrm{BW})\end{array}$ & $\begin{array}{l}\text { HFD+MET } \\
(25 \mathrm{mg} / \mathrm{kg} \mathrm{BW})\end{array}$ \\
\hline SOD $\left(\mathrm{U}^{*} / \mathrm{mg}\right.$ protein $)$ & $12.42 \pm 1.01^{\mathrm{a}}$ & $7.98 \pm 0.56^{6}$ & $9.54 \pm 0.77^{\mathrm{c}}$ & $11.29 \pm 0.70^{\mathrm{d}}$ \\
\hline CAT $\left(\mathrm{U}^{\#} / \mathrm{mg}\right.$ protein $)$ & $34.21 \pm 2.32^{\mathrm{a}}$ & $18.72 \pm 1.23^{\mathrm{b}}$ & $29.11 \pm 2.10^{\mathrm{c}}$ & $31.74 \pm 1.70^{\mathrm{d}}$ \\
\hline GPX $\left(\mathrm{U}^{*} / \mathrm{mg}\right.$ protein $)$ & $10.21 \pm 0.69^{\mathrm{a}}$ & $4.97 \pm 0.31^{\mathrm{b}}$ & $7.42 \pm 0.45^{\mathrm{c}}$ & $8.28 \pm 0.63^{\mathrm{d}}$ \\
\hline GSH ( $\mu \mathrm{g} / \mathrm{mg}$ protein) & $12.09 \pm 0.78^{\mathrm{a}}$ & $6.34 \pm 0.38^{\mathrm{b}}$ & $11.89 \pm 0.89^{\mathrm{a}}$ & $10.64 \pm 0.62^{\mathrm{d}}$ \\
\hline Vitamin $\mathrm{C}(\mu \mathrm{g} / \mathrm{mg}$ protein $)$ & $1.58 \pm 0.08^{\mathrm{a}}$ & $0.39 \pm 0.0 .01^{\mathrm{b}}$ & $0.92 \pm 0.04^{\mathrm{c}}$ & $1.21 \pm 0.07^{\mathrm{d}}$ \\
\hline Vitamin $\mathrm{E}(\mu \mathrm{g} / \mathrm{mg}$ protein) & $5.49 \pm 0.35^{\mathrm{a}}$ & $2.05 \pm 0.0 .18^{b}$ & $4.54 \pm 0.29^{\mathrm{c}}$ & $4.94 \pm 0.37^{\mathrm{d}}$ \\
\hline
\end{tabular}

$\mathrm{U}^{*}=$ enzyme concentration required to inhibit the NBT to $50 \%$ reduction in one minute.

$\mathrm{U}^{\#}=\mu$ mole of $\mathrm{H}_{2} \mathrm{O}_{2}$ consumed/minute. $\mathrm{U}^{*}=\mu \mathrm{g}$ of $\mathrm{GSH}$ utilized/minute. Values that have a different superscript letter $(a, b, c, d)$ differ significantly with each other $(p<0.05$,DMRT). 


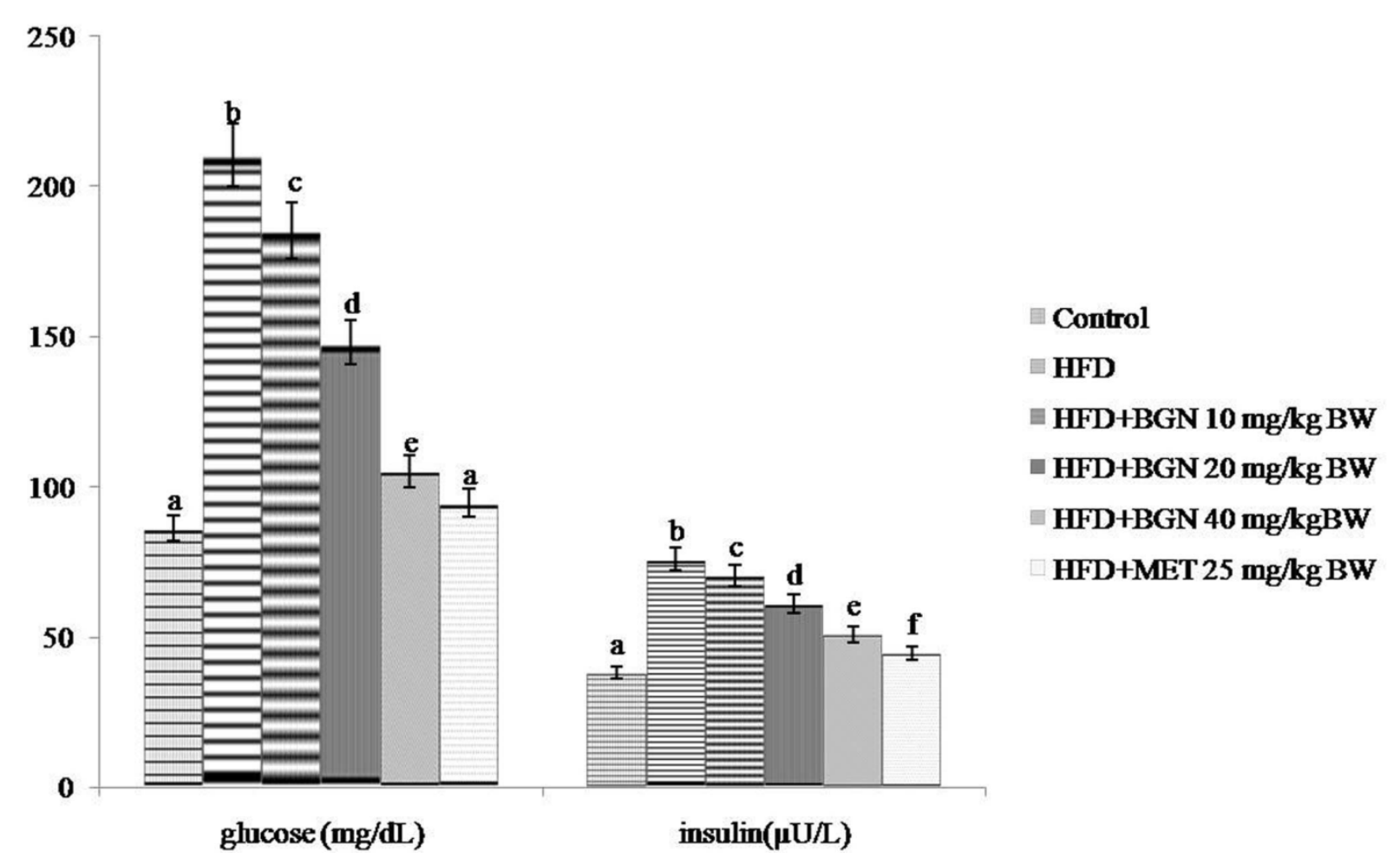

Figure 1. Effect of Bergenin on plasma glucose and insulin levels in HFD-fed C57BL/6J mice.Values that have a different superscript letter (a, b, c,d,e,f) differ significantly with each other $(\mathrm{p}<0.05$,DMRT). BGN-bergenin, MET-metformin
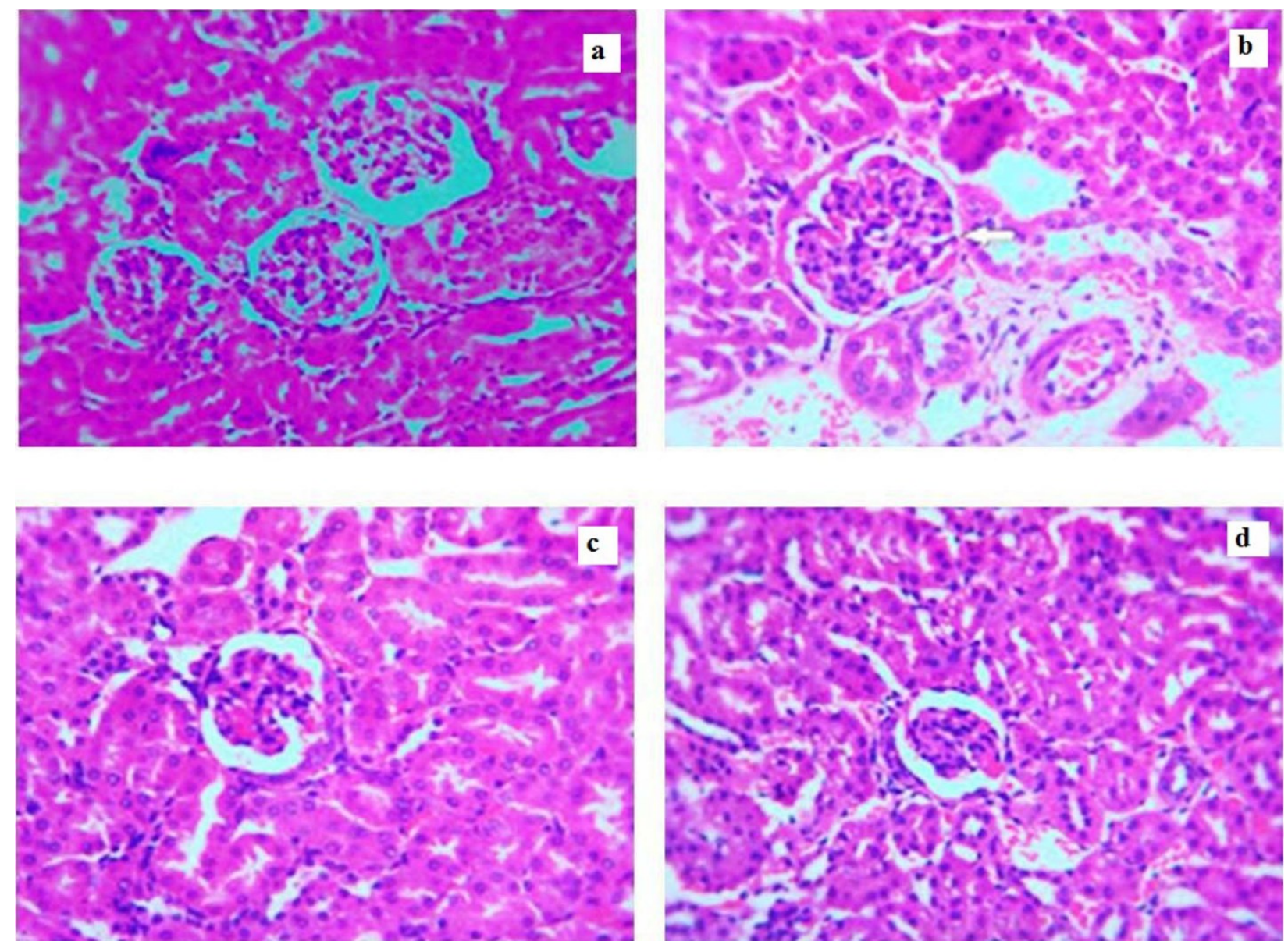

Figure 2. 2(a) normal control - normal glomeruli with closely packed tubules and normal medulla. 2(b) HFD- focal proliferative glomerulonephritis with mild increase in cellularity. 2(c) HFD+ Bergenin- normal glomeruli with closely packed tubules. 2(d) HFD+metformin- normal glomeruli and medulla. 


\section{References}

[1] American Diabetes Association, Diagnosis and classification of diabetes mellitus,Diabetes Care. 33 (2010) 62-69.

[2] D. Koya, M. Haneda, S. Inomata, Y. Suzuki, D. Suzuki, H. Makino, et al., Long-term effect of modification of dietary protein intake on the progression of diabetic nephropathy: A randomised controlled trial, Diabetologia. 52 (2009) 2037-45.

[3] T. Zelmanovitz , F. Gerchman, A.P. Balthazar, F.C. Thomazelli, J.D. Matos, L.H. Canani, Diabetic nephropathy, Diabetol Metab Syndr. (2009) 1-10.

[4] H.S. Lee, S.K. Ku, Effect of picrorrhiza rhizoma extracts on early diabetic nephropathy in streptozotocin-induced diabetic rats. J Med Food. 11(2008) 294-301.

[5] B.H. Havsteen, The biochemistry and medical significance of the flavonoids, Pharm Therap. 96 (2002) 67-202.

[6] Y.Y. Soong, P.J. Barlow, Antioxidant activity and phenolic of selected fruit seeds, Food Chem. 88 (2004) 411-417.

[7] V.P. Veerapur, K.R. Prabhakar, B.S. Thippeswamy, P. Bansal, K.K. Srinivasan, M.K. Unnikrishnan, Antidiabetic effect of Ficus racemosa Linn. Stem bark in high-fat diet and lowdose streptozocin- induced type 2 diabetic rats: A mechanistic study, Food Chem. 132 (2012) 186-193.

[8] H.K. Lim, H.S. Kim, H.S. Choi, S. Oh, J. Choi, Hepatoprotective effects of bergenin, a major constituent of Mallotus japonicus, on carbon tetrachloride-intoxicated rats, J Ethanopharmacol. 72, (2000) 469-474.

[9] M. Arfan, H. Amin, M. Karamac, A. Kosinska, W. Wiczkowski, R. Amarowick, Antioxidant activity of phenolic fractions of Mallotus philippinensis barks extract, Food Sci. 27 (2009) 109-117.

[10] R. Srinivasan, M.J.N. Chandrasekar, M.J. Nanjan, B. Suresh, Antioxidant activity of Caesalpinia digyna root, J Ethnopharmacol. 113(2007) 284-91.

[11] H.S. Kim, H.K. Lim, M.W. Chang, Y.C. Kim, Antihepatotoxic activity of bergenin, the major constituent of Mallotus japonicus, on carbon tetrachloride-intoxicated hepatocytes. J Ethnopharmacol. 69 (2000) 79-83.

[12] H.L. Pu, X. Huang, J.H. Zhao, A. Hing, Bergenin is the antiarrhythmic principle of Fluggea virosa. Planta Med. 68 (2002) 372-374.

[13] S. Piacente, C. Pizza, N. Detommasi, Constituents of Ardisia japonica and their invitro antiHIVactivity, J Nat Products. 59 (1996) 565-569.

[14] T. Swarnalakshmi, M.G. Sethuraman, N. Sulochana, R. Arivudainambi, A note on the antiinflammatory activity of bergenin, Curr Sci. 53(1984) 917.

[15] R. Kumar, D.K. Patel, S.K. Prasad, D. Laloo, S. Krishnamurthy, S. Hemalatha, Type 2 antidiabetic activity of bergenin from the roots of Caesalpinia digyna Rottler, Fitoterapia. 83 (2012) 395-401.

[16] P. Trinder, Determination of blood glucose using an oxidase peroxidase system with a non carcinogenic chromogen, J Clin Pathol. 22 (1969)158-161.

[17] W. Burgi, M. Briner, N. Franken, A.C.H. Kessler. One step sandwich enzyme immunoassay for insulin using monoclonal antibodies, Clin Biochem. 213, (1998) 11-314.

[18] J.K. Fawcett, J.E. Scott, A rapid and precise method for the determination of urea, J Clin Path. 3 (1960)156-159.

[19] W.T. Caraway, Determination of uric acid in serum by carbonate method, Am J Clin Path. 25 (1955) 840-845.

[20] P. Kakkar, B. Das, P.N. Viswanathan, A modified spectrophotometric assay of superoxide dismutase, Ind J Biochem Biophys. 21(1984)130-132. 
[21] A.K. Sinha, Colorimetric assay of catalase, Anal Biochem. 47 (1972) 389-394.

[22] J.T. Rotruck, A.L. Pope, H.E. Ganther, A.B. Swanson, D.G. Hafeman, W.G. Hoekstra. Selenium: biochemical role as a component of glutathione peroxidise, Science. 179 (1973) 588-590.

[23] G.L. Ellman, Tissue sulfhydryl groups, Arch Biochem Biophys. 82 (1959)70-77.

[24] C.A. Kuether and J.H. Roe, The determination of ascorbic acid in whole blood and urine through the 2, 4-dinitrophenylhydrazine derivative of dehydroascorbic acid, J Biol Chem. 11(1943) 145-164.

[25] H. Baker, O. Frank, B. DeAngelis, S. Feingold, Plasma tocopherol in man at various times after ingesting free or acetylated tocopherol, Nutr Res. 21 (1980) 531-536.

[26] W.G. Niehaus, B. Samuelsson. Formation of malondialdehyde from phospholipid arachidonate during microsomal lipid peroxidation, Eur J Biochem. 6 (1968)126-130.

[27] Z.Y. Jiang, J.V. Hunt, S.P. Wolff, Ferrous ion oxidation in the presence of xylenol orange for the detection of lipid hydroperoxides in low density lipoprotein, Anal Biochem. 202 (1992) 384-389.

[28] G. Reaven, F. Abbasi, T. McLaughlin, Obesity, insulin resistance, and cardiovascular disease, Recent Prog Horm Res. 59 (2004) 207-223.

[29] A. Sundaresan, R. Harini and K.V. Pugalendi, Ursolic acid and rosiglitazone combination alleviates metabolic syndrome in high fat diet fed C57BL/6J mice, Gen. Physiol. Biophys. 31 (2012) 323-333.

[30] R. Agarwal, N. Vasavada, N.G. Sachs, S. Chase, Oxidative stress and renal injury with intravenous iron in patients with chronic kidney disease, Kidney Int. 65 (2004) 2279-2289.

[31] S. Kume, T. Uzu, S. Araki, T. Sugimoto, K. Isshiki, M. Kanasaki, Role of altered renal lipid metabolism in the development of renal injury induced by a high-fat diet, J Am Soc Nephrol. 18 (2007) 2715-2723.

[32] M.L. Bournoville, M. Conti, R. Bazin, O. Michel, J. Bariety, J. Chevalier, Oxidative stress occurs in absence of hyperglycaemia and inflammation in the onset of kidney lesions in normotensive obese rats, Nephrol Dial Transpl. 15(1999) 467-476.

[33] M.O. Sim, J.R. Ham, H.I. Lee, K.I. Seo, M.K. Lee, Long-term supplementation of umbelliferone and 4-methylumbelliferone alleviates high-fat diet induced hypertriglyceridemia and hyperglycemia in mice, Chem-Biol Inter. 216 (2014) 9-16.

[34] K. Datta, S. Sinha, P. Chattopadhyay, Reactive oxygen species in health and diseases, Natl Med J India, 13(2000) 304-10.

[35] K. Arai, S. Maguchi, S. Fujii, H. Ishibashi, K. Oikawa, N. Taniguchi, Glycation and inactivation of human $\mathrm{Cu}-\mathrm{Zn}$-superoxide dismutase, J Biol Chem. 262 (1987) 16969-72.

[36] N. Nazir, S. Koul, M.A. Qurishi, M.H. Najar, M.I. Zargar, Evaluation of antioxidant and antimicrobial activities of Bergenin and its derivatives obtained by chemoenzymatic synthesis, European J Med Chem. 46 (2011) 2415-2420.

[37] E.F. Kern, P. Erhard, W. Sun, S. Genuth, M.F.Weiss, Early urinary markers of diabetic kidney disease: A nested case-control study from the Diabetes Control and Complications Trial (DCCT), Am J Kidney Dis. 55 (2010) 824-34.

[38] V.C. Myers, M.S.Fine, Comparative distribution of urea, creatinine, uric acid and sugar in the blood and spinal fluid, Am J Med Sci, 76 (1918) 239-244.

[39] T. Yokozawa, T. Nakagawa, T. Oya, T. Okubo, L.R. Juneja, Green tea polyphenols and dietary fibre protect against kidney damage in rats with diabetic nephropathy, J Pharm Pharmacol. 57 (2005) 773-80. 